\title{
Effect of defunctionalization on colon carcinogenesis in the rat
}

\author{
S. Pérez-Holanda, L. Rodrigo' ${ }^{1}$ J. Viñas-Salas ${ }^{2}$, C. Piñol-Felis ${ }^{2}$ and C. Ildefonso ${ }^{3}$ \\ Department of Surgery. Hospital Valle del Nalón. Langreo, Asturias. 'Department of Gastroenterology. School of \\ Medicine. Oviedo University. Oviedo, Asturias. ${ }^{2}$ Department of Internal Medicine and Surgery. School of Medicine. \\ Hospital Arnau de Vilanova. Lleida University. Lleida. ${ }^{3}$ Department of Surgery. Hospital Grande Covián. Arriondas, \\ Asturias. Spain
}

\begin{abstract}
Objective: to examine the effect of fecal absence on experimental colon carcinogenesis in both male and female rats.

Material and methods: a total of 138 10-week-old SpragueDawley, male and female rats were divided into five groups: A) 20 rats, no treatment; B) 26 rats, colonic defunctionalization; C) 30 rats, 18 weekly doses of dimethylhydrazine $(\mathrm{DMH}), 21 \mathrm{mg} / \mathrm{kg}$ body weight each, from the beginning of the study; D) 20 rats, ethylen-diamine-tetraacetic acid for 18 weeks; and E) 42 rats, same surgical procedure as rats in group B plus DMH injections at the same doses as rats in group $\mathrm{C}$. Animals were sacrificed after 25-27 weeks. Number of tumors, their location, and pathological findings were all compared between groups.

Results: no tumors developed in the dimethylhydrazine-free groups. No differences were obtained either in number of tumors or tumors per rat for group C as compared to group E. Fecal absence was associated with smaller-sized tumors $(p=0.007)$, greater numbers of non-mucinous tumors $(p=0.00009)$, better differentiation $(p=0.0054)$, and lesser penetration into the wall $(p=0.015)$ for group $E$ as compared to group $C$. In the dimethylhydrazine group, fecal absence altered the number of tumors developing in males as compared to female rats $(p=0.025)$. Moreover, this fecal absence showed no inhibitory effect on right colonic tumors $(p=0.0065)$.

Conclusions: fecal absence alters the DMH-carcinogenic pattern in the defunctionalized colon when using an experimental model in both male and female rats.
\end{abstract}

Key words: Cancer. Carcinogenesis. Colon. Defunctionalization. Dimethylhydrazine. Neoplasm. Tumors.

Pérez-Holanda S, Rodrigo L, Viñas-Salas J, Piñol-Felis C, Ildefonso $C$. Effect of defunctionalization on colon carcinogenesis in the rat. Rev Esp Enferm Dig 2006; 98: 644-654.

Recibido: 19-02-06.

Aceptado: 17-05-06.

Correspondencia: S. Pérez-Holanda, Castiello, 22. 33394 Gijón. Fax: 985 134 108. e-mail: sergio.perez-holanda @ sespa.princast.es

\section{INTRODUCTION}

Colorectal cancer (CRC) is a frequent tumor, with an elevated mortality in Western countries (1). It is the second cancer in the population of Asturias (Northern Spain), representing $13 \%$ of the total number of cases of cancer, which are diagnosed annually, and causes $3.7 \%$ of the total number of deaths and $14.1 \%$ of the deaths due to cancer (2). In a meta-analysis made concerning its possible pathogenesis it has been clearly shown that environmental factors play a significant role in its induction (3). In fact, the incidence rate could be reduced in approximately $30-35 \%$, by means of the modification of eating habits (4). The fecal absence could have a protector effect on the incidence of colon cancer in experimental models (5), although the tumors induced, both in the excluded and in the functional segments, showed no histological differences (6), the carcinogenesis could be different in the left and right colon, and therefore differences could exist between them (7).

Nevertheless, it seems that tumors which develop in a segment in contact with feces, would be of greater size and number, than those which develop in a defunctionalised segment $(8,9)$. Gender factor could play a role on differences found in colonic carcinogenesis.

In order to study the influence of the different etiological environmental factors, on colon cancer in man, long-term prospective studies are difficult to carry out (10).

The induction of colorectal cancer with 1-2 dimethylhydrazine $(\mathrm{DMH})$ in rats, is a currently valid experimental model, transferable to humans, both in their macromicroscopic and clinical behavior (11-13).

The aim of the present study was to investigate the effect of the absence of feces, in the colon of the rats, subjected to colonic tumor induction with DMH. 


\section{MATERIAL AND METHODS}

No preoperative preparations were carried out. An end-to-side ileorectal anastomosis was made in the rats of groups $\mathrm{B}$ and $\mathrm{E}$ as follows:

-Weighing and preparing the anesthetic: chloral hydrate (Panreac ${ }^{\circledast}$, Barcelona) $-4.5 \%$ to $1 \mathrm{ml} / 100 \mathrm{~g} /$ body weight, intraperitoneally (400 mg/kg/weight) (14).

-Injection of anesthetic, and shaving and placement of animal.

-Placement of optic microscope focusing on the abdomen, with a $4 x$ magnification lens.

-Application of a local antiseptic and performance of an abdominal incision $2.5-3 \mathrm{~cm}$ in length. Placement of a fenestrated sheet $(15,16)$.

- Localization and ileal section at $5 \mathrm{~mm}$ from the ileocecal valve (17), proximal and distal ligatures of the arterial branch, and ligature with a silk 4/0 suture (18).

- Ligature using a silk $2 / 0$ suture of the terminal ileum, and section of the proximal end (19).

- Rectal incision $-5 \mathrm{~mm}$ to $3 \mathrm{~cm}-$ of the anus (9).

-End-to-side ileorectal anastomosis with silk 4/0 monofilament suture, and two semi-continuous sutures with full stitches.

- Closure of the wall, with continuous monofilament silk $2 / 0$ suture, and also of the skin, with simple stitches.

The procedure was approximately 35 minutes long, and the rat was then put back in the cage in a lateral position.

The starting of oral tolerance was permitted from the time of wakening. The reintroduction of dietary pellets in the dispensers was made 12 hours afterwards. Feces of soft consistency and normal color appeared at 48 hours. DMH injections were started 7 days after the procedure $(20,21)$.

A minimum number of 20 rats per group was established in order to achieve a tumoral induction of $76-90 \%$ of the rats $(22,23)$, for a rate of DMH-induced tumors per rat of 1.87 and high mortality (20,24-27).

In all, 138 10-week-old "Sprague-Dawley" rats (Lab. Letica $^{\circledR}$, Barcelona, Spain), both males and females from the same genetic line, were distributed into five groups: A) none of the rats received any kind of treatment; B) 26 rats were subjected to colonic defunctionalization; C) 30 rats were included due to the high mortality obtained in this same group in previous studies (23-25). They received 18 subcutaneous (s.c.) weekly injections (s.c.) of $21 \mathrm{mg} / \mathrm{kg}$. wt. of 1-2 dimethylhydrazine (DMH; Fluka Chemica A.G., Sigma Co. ${ }^{\circledR}$, St. Louis, Missouri, USA) from age 10 weeks. The DMH solution was prepared weekly $(23,28)$. Injections were applied in the lumbar region; D) 20 rats received the same volume of EDTA solution as seen in group $\mathrm{C}$, mixed with distilled water and without DMH; and E) 42 rats were included due to the high mortality obtained in this same group in previous studies (26). They were operated on with the same technique as group B, and on the eighth day (20) were treated with the same weekly subcutaneous injections as group $\mathrm{C}$. In order to compare tumors in group $\mathrm{C}$ and tumors in group $\mathrm{E}$, those located in the descending portion, anastomosis, and rectum of operated rats were excluded from the study.

The feeding of all rats (ITM-R20 diet, Lab. Letica ${ }^{\circledR}$, Barcelona, Spain) contained 3\% fat and 5\% fiber. The quantity of food consumed by rats was monitored throughout the study $-50 \%$ of animals in each group were weighed weekly until sacrificed. Room conditions were maintained at constant temperature and humidity, and rats were subjected to a circadian 12-hour cycle of light-darkness $(15,29)$. The animals were separated in cages with a maximum of three per cage, in order to avoid autophagia as in previous studies $(23-25,28)$. Animals of different gender were not mixed together in order to avoid aggression.

Both the recommendations by the European Ethics Committee (E.C. Directive 1986/609) and "Real Decreto $1201 / 2005$ " regarding the treatment of experimental animals were followed throughout the study.

Surviving rats were sacrificed between weeks 25 and 27 of the study by means of the intraperitoneal instillation of a lethal dose of $4.5 \%$ chloral hydrate. A fixed and equal number of rats from each group were sacrificed each week $(23,28)$.

At necropsy, the thoracic and abdominal cavities were examined. A register was made of the number of tumors, their localization and size. Tumor size was measured as mean \pm SD (in squared millimeters, obtained from maximum diameters) $(28,30)$. Samples of tumors were later taken for histological study, both from the cecum and the ascending colon (right colon), and the transverse and descending colon (left colon). These samples were fixed and prepared by means of hematoxyline-eosine staining. The lesions in the colonic mucosa were classified according to criteria by Grau Castro and Piqué Badía (31) and Lev (32). The tumors observed were classified according to parietal invasion extent, differentiation, and histological type (defining them as mucinous carcinoma when this component was greater than 50\%), association with a lymphoid plaque, size, and macroscopic appearance. Other findings were also recorded.

Data obtained were analyzed using the SPSS software program. A bivariant analysis was used to compare $\mathrm{DMH}$ (C) and $\mathrm{DMH}+$ procedure (E) groups, and differences found were analyzed. In cases where requirements for the application of the chi-squared test were not met, a corrected Fisher's exact test was used. Differences between both groups were considered significant when the p-value was less than or equal to 0.05 .

Results are presented as mean \pm standard deviation (SD).

\section{RESULTS}

A total of 27 rats $(19.6 \%)$ died before study completion, $10(38.5 \%)$ rats in group B, $2(6.7 \%)$ in group C, and $15(35.7 \%)$ in group E.

Five male rats died in group B (mortality: 80\%), in 2 cases because of fecal peritonitis secondary to suture dehis- 
cence (within $72 \mathrm{~h}$ ), in one due to occlusion of the blind loop in the excluded colon, and one from occlusion and stenosis at the anastomosis (within the first week). Within the same group, 6 out of 21 female rats did not complete the study $(28.6 \%)$ : one died in the fifth postoperative week due to an obstruction of the small intestine as a result of adhesions; another died in the seventh postoperative week with extreme cachexia and liquid stools, with no tumor; one case of cannibalism was seen in the ninth week; in 3 cases no justified cause was found for death, which occurred during the tenth, twelfth and thirteenth postoperative week.

In group $\mathrm{C}$ one male rat and one female rat died early, but the cause of death could not be identified - no tumor was identified at autopsy.

In group E 12 out of 21 male rats died (57.1\%): 4 from suture dehiscence and secondary fecal peritonitis within the first 72 hours; 3 from occlusion of the small intestine ( 7 days after the procedure); 2 males at the twentieth and twenty second weeks of life, their study not being possible due to cannibalism; a further 2 died from colon tumors, their study not being possible due to considerable tissue deterioration (tissues were fixed in paraffin, but the structures were not identifiable under the microscope); another male died from an occlusive tumor at the anastomosis. In female rats 3 early deaths were seen (14.3\%): 1 due to an occlusion of the defunctionalized colon within the first 7 days after the procedure; another (at 14 weeks) showed an ischemic appearance of the small intestine due to adhesions; the third rat (at 14 weeks) died with a necrotic ulcer at the anastomosis.

In groups B and E, 80 and $57.1 \%$-respectively- of males were lost, as were 28.6 and $14.3 \%$ of females, respectively (Fisher's exact test, $\mathrm{p}=0.31$ ).

The postoperative mortality of operated rats was $17.6 \%$ (12 of 68); for males this was $42.3 \%$ (11 out of 26 ), for females $2.4 \%$ ( 1 out of 42$)$ ( $p<0.00001)$.

No significant differences were found between the weight of the animals in group $\mathrm{C}$ and group $\mathrm{E}$ (Table I). In group E tumors were located as follows: 2 in the ascending colon, 4 in the transverse colon, 4 in the defunctionalized descending colon, 10 in the anastomosis area, and 13 in the rectum. For rats in group $\mathrm{E}$, the excluded segments had a significantly smaller length when compared with those in group $\mathrm{C}$, both in males and females (Table I).

In groups A, B and D no tumors were found. There were 25 tumors in the DMH group (28 rats), and 10 in group E (27 rats) (Table II).

We found a smaller number of tumor-free male rats as compared to tumor-free females, both in the rats of group $\mathrm{C}(14.3$ vs. $78.6 \% ; \mathrm{p}=0.0006)$ and group $\mathrm{E}(0$ vs. $50 \%$; $=0.011$ ) (Table II). In the presence of carcinogen, the natural predominance of males over females regarding the development of a greater number of colonic cancers was altered by the effect of fecal absence -the proportion of tumors in females was $12 \%$ in group $\mathrm{C}$ and $50 \%$ in group $\mathrm{E}(\mathrm{p}=0.025)$ (Table II).

With respect to the macroscopic characteristics studied, tumors of the excluded segments in group $\mathrm{E}$ were
Table I. Morphological description of sample

\begin{tabular}{|c|c|c|}
\hline & DMH group $(C)$ & $D M H+S I$ group $(E)$ \\
\hline \multicolumn{3}{|c|}{ Weight in g. (mean \pm SD) } \\
\hline $\begin{array}{l}\text { Males } \\
\text { Females }\end{array}$ & $\begin{array}{l}505.47 \pm 62.62 \\
322.01 \pm 27.36\end{array}$ & $\begin{array}{l}521.67 \pm 108.89 \\
314.44 \pm 49.67\end{array}$ \\
\hline \multicolumn{3}{|c|}{ Length of colon in males in cm (mean \pm SD) } \\
\hline Cecum & \multicolumn{2}{|c|}{$(p<0.001)$} \\
\hline Ascending & \multicolumn{2}{|c|}{$(p<0.001)$} \\
\hline Transverse & \multicolumn{2}{|c|}{$(p=0.016)$} \\
\hline \multicolumn{3}{|c|}{ Length of colon in females in $\mathrm{cm}($ mean $\pm \mathrm{SD})$} \\
\hline Cecum & \multicolumn{2}{|c|}{$\begin{array}{c}4.60 \pm 0.55 \quad 2.44 \pm 0.62 \\
(p<0.001)\end{array}$} \\
\hline Ascending & \multicolumn{2}{|c|}{$3.22 \pm 0.65(p<0.001)$} \\
\hline Transverse & $3.57 \pm 0.62$ & $2.39 \pm 0.63$ \\
\hline
\end{tabular}

SD: standard deviation; DMH: dimethylhydrazine; SI: surgical intervention.

Table II. Tumor incidence and distribution

\begin{tabular}{lcc}
\hline & DMH group (C) & DMH + S/ group (E) \\
\hline Number of rats sacrificed, $\mathrm{n}(\%)$ & $28(93.3 \%)$ & $27(64.3 \%)$ \\
Male/Female, $\mathrm{n}$ & $14 / 14$ & $9 / 18$ \\
Number of tumor-free rats, $\mathrm{n}(\%)$ & $13(46.4 \%)$ & $9(33.3 \%)$ \\
$\quad$ Males, $\mathrm{n}(\%)$ & $2 / 14(14.3 \%)$ & $0 / 9(0 \%)$ \\
$\quad$ Females, $\mathrm{n}(\%)$ & $11 / 14(78.6 \%)^{*}$ & $9 / 18(50 \%)^{* *}$ \\
Total number of tumors, $\mathrm{n}$ & 25 & 10 \\
$\quad$ Males/Females, $\mathrm{n}$ & $22 / 3$ & $5 / 5$ \\
& \multicolumn{2}{c}{$(\mathrm{p}=0.025)$} \\
Mean number of tumors/rat (mean \pm SD) & $1.67 \pm 1.23$ & $0.37 \pm 0.99$ \\
$\quad$ Males & $1.83 \pm 1.34$ & $0.40 \pm 0.83$ \\
Females & $1.00 \pm 0.00$ & $0.35 \pm 1.17$ \\
\hline
\end{tabular}

Females vs. males: *Within the $\mathrm{DMH}$ group, $\mathrm{p}=0.0006: * *$ Within the $\mathrm{DMH}+\mathrm{SI}$ group, $p=0.011$; SD: standard deviation; $\mathrm{DMH}$ : dimethylhydrazine; SI: surgical intervention; n: number of tumors.

smaller in size versus those in group $\mathrm{C}(\mathrm{p}=0.007)$. However, no significant differences were found regarding their appearance or localization (Table III).

In relation to the microscopic characteristic of tumors (Table IV), in the excluded segments (group E) a greater number of adenocarcinomas was seen versus mucinous carcinomas ( $\mathrm{p}=0.00009)$, as well as a greater degree of tumor differentiation $(\mathrm{p}=0.0054)$, and a smaller degree of parietal invasion $(\mathrm{p}=0.015)$ when compared to the tumors of the defunctionalized segments of group C. No differences were found between both groups in the association of tumors with lymphoid tissue.

The rats in group $\mathrm{C}$ had a greater number of mucinous carcinomas in the right colon $(75 \%)$ when compared to the left colon $(17.6 \%)(p=0.006)$. Significant differences were observed with respect to group $\mathrm{E}(\mathrm{p}=0.0065)$, in which the adenocarcinoma type predominated both in tu- 
Table III. Macroscopic characteristics of tumors

\begin{tabular}{|c|c|c|}
\hline & $\begin{array}{l}\text { DMH group (C) } \\
\quad(n=25)\end{array}$ & $\begin{array}{c}D M H+S I \text { group }(E) \\
(n=10)\end{array}$ \\
\hline \multicolumn{3}{|c|}{ Tumor area in $\mathrm{mm}^{2}($ mean $\pm \mathrm{SD})$} \\
\hline Global & \multicolumn{2}{|c|}{$(p=0.007)$} \\
\hline $\begin{array}{l}\text { Males } \\
\text { Females }\end{array}$ & $\begin{array}{c}59.45 \pm 167.40 \\
25.67 \pm 33.65\end{array}$ & $\begin{array}{c}1.0 \pm 0.00 \\
20.33 \pm 14.01\end{array}$ \\
\hline \multicolumn{3}{|l|}{ Macroscopic aspect } \\
\hline Polypoid, n (\%) & $20(80 \%)$ & $1(10 \%)$ \\
\hline Flat, $n(\%)$ & $2(8 \%)$ & $4(40 \%)$ \\
\hline Infiltrating, n (\%) & $3(12 \%)$ & $5(50 \%)$ \\
\hline \multicolumn{3}{|l|}{ Distribution } \\
\hline Right colon, n (\%) & $8(32 \%)$ & $6(60 \%)$ \\
\hline Left colon, n (\%) & $17(68 \%)$ & $4(40 \%)$ \\
\hline
\end{tabular}

SD: standard deviation; $\mathrm{DMH}$ : dimethylhydrazine; SI: surgical intervention; $\mathrm{n}$ : number of tumors.

Table IV. Microscopic characteristics of tumors

\begin{tabular}{|c|c|c|}
\hline & $\begin{array}{l}\text { DMH Group (C) } \\
\quad(n=25)\end{array}$ & $\begin{array}{c}D M H+S I \text { Group }(E) \\
\quad(n=10)\end{array}$ \\
\hline $\begin{array}{l}\text { Adenocarcinomas, n (\%) } \\
\text { Mucinous type, n (\%) }\end{array}$ & $\begin{array}{l}16(64 \%) \\
9(36 \%) \\
(p=\end{array}$ & $\begin{array}{r}10(100 \%) \\
0(0 \%) \\
00009)\end{array}$ \\
\hline $\begin{array}{l}\text { Degree of differentiation } \\
\text { Good, } n(\%)\end{array}$ & $5(20 \%)$ & 0054) $10(100 \%)$ \\
\hline $\begin{array}{l}\text { Moderate, n (\%) } \\
\text { Poor, n (\%) }\end{array}$ & $\begin{array}{l}8(32 \%) \\
12(48 \%)\end{array}$ & $\begin{array}{l}0(0 \%) \\
0(0 \%)\end{array}$ \\
\hline $\begin{array}{l}\text { Degree of invasion } \\
\text { In situ, } \mathrm{n}(\%)\end{array}$ & $5(20 \%)$ & $.015)^{8(80 \%)}$ \\
\hline $\begin{array}{l}\text { Spread to the peritoneum, } \mathrm{n}(\%) \\
\text { Other, } \mathrm{n}(\%)\end{array}$ & $\begin{array}{c}1(4 \%) \\
19(76 \%)\end{array}$ & $\begin{array}{l}1(10 \%) \\
1(10 \%)\end{array}$ \\
\hline Associated lymphoid tissue, $\mathrm{n}(\%)$ & $7(28 \%)$ & $4(40 \%)$ \\
\hline
\end{tabular}

DMH: dimethylhydrazine; SI: surgical intervention; n: number of tumors.

mors located in the right $(100 \%)$ and the left colon (100\%) (Table V).

A tumor of the small intestine was found in a rat of group $\mathrm{C}$, as was an ear tumor in a rat of this same group. In group $\mathrm{E}$ a male rat developed peritoneal carcinomatosis, and a female rat had multiple liver and spleen metastases, these being confirmed microscopically.

\section{DISCUSSION}

Overall mortality is high for experimental studies in rats including surgical procedures (28); for this reason their performance is low $(16,33,34)$. In our study we lost $19.6 \%$ of rats, including those groups undergoing no procedure. Our postoperative mortality was low (17.6\%), which also represents appropriate performance $(7,18,35)$. Furthermore, we obtained better results in female versus male rats.
Table V. Tumor characteristics according to localization

\begin{tabular}{|c|c|c|}
\hline & $\begin{array}{l}\text { DMH group }(C) \\
\quad(n=25)\end{array}$ & $\begin{array}{c}D M H+S I \operatorname{group}(E) \\
(n=10)\end{array}$ \\
\hline $\begin{array}{l}\text { Right colon, } \mathrm{n} \\
\text { Tumor size in } \mathrm{mm}^{2}(\text { mean } \pm \text { SD) } \\
\text { Adenocarcinomas, } \mathrm{n}(\%)\end{array}$ & $\begin{array}{c}8 \\
12.95 \pm 27.29 \\
2(25 \%) \\
(p=\end{array}$ & $\begin{array}{c}6 \\
2.50 \pm 3.39 \\
6(100 \%) \\
.0065)\end{array}$ \\
\hline Mucinous carcinomas, n (\%) & $6(75 \%)^{*}$ & $0(0 \%)$ \\
\hline $\begin{array}{l}\text { Left colon, } \mathrm{n} \\
\text { Tumor size in } \mathrm{mm}^{2} \text { (mean } \pm \text { SD) } \\
\text { Adenocarcinomas, } \mathrm{n}(\%) \\
\text { Mucinous carcinomas, } \mathrm{n}(\%)\end{array}$ & $\begin{array}{c}17 \\
20.53 \pm 21.62 \\
14(82.4 \%) \\
3(17.6 \%)\end{array}$ & $\begin{array}{c}4 \\
15.75 \pm 14.66 \\
4(100 \%) \\
0(0 \%)\end{array}$ \\
\hline
\end{tabular}

In our study, defunctionalized colonic segments were significantly smaller in length when compared to the DMH control group both in males and females. This finding has been described as secondary to atrophy, both macroscopically and microscopically $(7,36)$.

An incidence of spontaneous experimental colonic carcinogenesis of less than 2-3/100.000 rats observed is reported (37). In the absence of carcinogen $(\mathrm{DMH})$ rats developed no tumors, as expected.

The model of colonic carcinogenesis with 1,2-dimethylhydrazine $(\mathrm{DMH})$ in rats is a valid model with similar results in human pathology (11-13), with mutagenic properties (38) and an additive effect both via the blood and luminal routes (11). The existence of spread via the hematogenous route may explain that no remission of carcinogenesis occurred in the excluded colon of operated DMH-induced rats.

In Spain the incidence of colorectal cancer (CRC) increased from around 10 cases/100.000 inhabitants/year in $1990(39,40)$ to 32 cases in $1998(41)$. When stratified according to gender, this is higher for males than for females (42). The epidemiological experience of finding a lower incidence of CRC in females was also reproducible in our model.

In this experimental study of carcinogenesis with $\mathrm{DMH}$ we found a significantly smaller number of tumorfree male rats versus female rats in both groups $\mathrm{C}$ and $\mathrm{E}$. Different authors show a smaller risk of CRC associated with the use of oral contraceptives or early age at first pregnancy (43); it has also been suggested (44) that hormone replacement therapy may reduce the risk of adenomatous polyps in the colon. The remission of male predominance regarding proportion of tumors in group $\mathrm{E}$ seems to be a contradictory result as regards the hypothesis of a hormonal protective factor for CRC. In an important study by Group for the Prevention of Polyps (45) it is postulated that the humoral protective effect, as compared to CRC in females, depends on the intraluminal route of carcinogenesis, fecal concentration of secondary bile acids, and modulation of the calcium absorption by colonic tumor cells. In our rats subjected to defunctional- 
ization no protective effect of the intraluminal route was found.

Epidemiological studies show that the incidence of CRC increases with age. In our study, the control group initiated tumor induction with $\mathrm{DMH}$ at week 10, while the group operated on did so at week 11. This may suggest a mistake in the design of the study. An experimental study comparing tumor induction according to age (young vs. old animals) (46) has shown an equal risk of $\mathrm{CRC}$ in both cases. Other authors have observed a greater risk of CRC in animals with tumor induction at a later age, associated with various both coenzyme (47) and enzyme (48) deficiencies. Thus, it does not seem that the difference in one week at tumor induction onset in our rats may have influenced our results, with the least tumor induction corresponding to the group of older age, and not the other way around.

The size of tumors induced in defunctionalized segments was significantly smaller when compared to the DMH control group. This effect, already commented on by various authors (49) over several decades, appears to be explained on the basis of a slower progression of the adenoma-carcinoma sequence (8). Different authors show that the smaller size of these tumors is due on the one hand to the absence of an intraluminal administration of $\mathrm{DMH}$, and on the other hand to the absence of the cocarcinogenic effect of feces $(1,32,50-53)$.

The greater incidence of tumors in the left colon by DMH can be explained by the greater susceptibility of the mucosa, a higher concentration of carcinogen after fecal dehydration, and a reduction of intestinal transit in this colonic segment (54). In paired experimental studies $(54,55)$ the index of aberrant crypts induced by $\mathrm{DMH}$ in the left colon is high -this effect was not seen in the right colon of the same animals, and this is in favor of a higher adenoma-carcinoma sequence in the left colon and de novo carcinogenesis in the right colon (7). In our rats no significant differences were found in tumor number or size in the right colon of rats in the control group versus the group with a defunctionalized right colon. These findings suggest that fecal absence in the right colon does not play an important role in carcinogenesis in this segment, which is in agreement with the aforementioned authors. Our results disagree with other studies (6) that suggest that colonic tumors induced both in the excluded and functional segments do not show histological differences amongst themselves, since, while the left colon showed this behavior, the right colon in our animals did not.

Different studies associate the right-side localization of tumors with a different histological differentiation $(28,51)$. In our study a significantly greater number of mucinous carcinomas was found in the right colon of the rats within the control group, versus the left colon of these same animals. Such behavior was not significant in rats within the $\mathrm{DMH}+$ procedure group, where the predominance of tumors in the right colon corresponded to well-differentiated forms of the adenocarcinoma type, an effect comparable to the behavior of this disease in humans (54).

Based on our experimental findings we can conclude that:

- The microscopic characteristics of colon tumors in excluded segments were significantly less aggressive versus the control group.

- The absence of fecal contact in the right colon has a modifying effect on colonic carcinogenesis in this segment -in our model induced by DMH- regarding the histological types found.

- In female versus male rats we found a significantly greater resistance against external aggression (procedures) and carcinogenic chemical agents (DMH).

\section{REFERENCES}

1. Greenwald P. Colon cancer overview. Cancer 1992; 70 (Supl. 5): $1206 \mathrm{~s}-15 \mathrm{~s}$.

2. Rayón Suárez C. Programa de Atención al Cáncer 2005-2007. Servicio de Salud del Principado de Asturias. Servicio de Publicaciones del Principado de Asturias. Oviedo: Imprenta Narcea SL, 2005. p. 31.

3. Trock B, Lanza E, Greenwald P. Dietary fiber, vegetables and colon cancer: Critical review and meta-analyses of the epidemiologic evidence. J Natl Cancer Inst 1990; 82: 650-61.

4. Vargas PA, Alberts DS. Primary prevention of colorectal cancer through dietary modifications. Cancer 1992; 70: 1229-35.

5. Nigro ND, Bull AW. Experimental intestinal carcinogenesis. Br J Surg 1985; 72 (Supl. 9): S36-7.

6. Rubio CA, Nylander G. Further studies on the carcinogenesis of the colon of the rat with special reference to the absence of intestinal contents. Cancer 1981; 48: 951-3.

7. Celik C, Mittelman A, Paolini NS, Lewis D, Evans JT. Effects of 1,2symmetrical-dimethylhydrazine on jejunocolic transposition in Sprague-Dawley rats. Cancer Res 1981; 41: 2908-11.

8. Rubio CA, Nylander G, Santos M. Experimental colon cancer in the absence of intestinal contents in Sprague-Dawley rats. J Natl Cancer Inst 1980; 3 (64): 569-72.

9. Lewin MR, Ferulano GP, Cruse JP, Clark CG. Experimental colon carcinogenesis is facilitated by endogenous factors in the intestinal contents. Carcinogenesis 1981; 2: 1363-6.

10. Weisburger JH. Causes, relevant mechanisms and prevention of large bowel cancer. Semin Onco 1991; 18: 316-36.

11. Banerjee A, Quirke P, Path FRC. Experimental models of colorectal cancer. Dis Colon Rectum 1998; 41: 490-505.

12. Barkla DH, Tutton PJ. Ultrastructure of 1,2-dimethylhydrazine-induced adenocarcinomas in rat colon. J Natl Cancer Inst 1978; 61: 1291-9.

13. Druckrey H, Preussman R, Matzkies F. Selektive Erzeugung von Darmkaebs bei Ratten durch 1,2-Dimethylhydrazin. In: Barkla DH, Tutton PJ. Ultrastructure of 1,2-dimethylhydrazine-induced adenocarcinomas in rat colon. J Natl Cancer Inst 1978; 61: 1291-9.

14. Pérez-Ruiz L, Gómez Quiles L. ¿Protege la colostomía proximal la anastomosis colo-cólica? Estudio experimental. Coloproctology 1993; 9 (3): 83-6.

15. Hardman WE, Cameron IL. Colonic crypts located over lymphoid nodules of 1,2-dimethylhydrazine-treated rats are hyperplastic and at high risk of forming adenocarcinomas. Carcinogenesis 1994; 15: 2353-61.

16. Zhang J, Lam LK. Colonoscopic colostomy model in rats for colon tumorigenesis studies. Carcinogenesis 1994; 15 (8): 1571-6.

17. Brink MA, Méndez-Sánchez N, Carey MC. Bilirubin cycles enterohepatically after ileal resection in the rat. Gastroenterol 1996; 110: 1945-57. 
18. Heppell J, de Zubiria M, Brais MF, Durh MA, Carioto S, Boivin Y, et al. An assessment of the risk of neoplasia in long-term ileal resevoirs using the DMH-rodent model. Dis Colon Rectum 1990; 33 (1): 26-31.

19. Salim AS. Removing oxygen-derived free radicals delays hepatic metastases and prolongs survival in colonic cancer: A study int the rat. Oncology 1992; 49 (1): 58-62.

20. Noguera Aguilar JF, Tortajada Collado C, Morón Canis JM, Plaza Martínez A, Amengual Antich I, Pujol Tugores JJ. Modelo experimental para el estudio de la recidiva locorregional del cáncer colorrectal. Rev Esp Enferm Dig 2002; 94 (3): 131-8.

21. Chang WW. Morphological basis of multistep process in experimental colonic carcinogenesis. Virchows Arch B Cell Pathol Incl Mol Pathol 1982; 41 (1-2): 17-37.

22. Hupp T, Buhr HJ, Ivancovic S, Beck N. Animal experiment studies of carcinogen-induced tumour development in colostomies in relation to suture materials. Langenbecks Arch Chir 1992; 377 (1): 9-13.

23. Viñas Salas J, Biendicho Palau P, Piñol Felis C, Miguelsanz García S, Pérez-Holanda S. Calcium inhibits colon carcinogenesis in an experimental model in the rat. Eur J Cancer 1998; 34: 1941-5.

24. Buenestado García J, Reñé Espinet JM, Piñol Felis C, Viñas Salas J. Modelo experimental de cáncer colorrectal. Rev Esp Enferm Dig 2002; 94 (6): 367-71.

25. Buenestado García J, Piñol Felis C, Reñé Espinet JM, Pérez-Holanda $\mathrm{S}$, Viñas Salas J. Silk suture promotes colon cancer in an experimental carcinogenic model. Dig Liver Dis 2002; 34 (8): 609-10.

26. Viñas-Salas J, Piñol Felis C, Fermiñán A, Egido R, Pérez-Holanda S, Biendicho $\mathrm{P}$, et al. Traumatismos repetitivos sobre la mucosa promueven cáncer de colon en un modelo experimental en ratas. Rev Esp Enferm Dig 2001; 93 (3): 140-7.

27. Noguera Aguilar JF, Amengual Antich I, Plaza Martínez A, Tortajada Collado C, Morón Canis JM, Pujol Tugores JJ. Influencia de la manipulación quirúrgica del colon en la carcinogénesis cólica inducida en ratas. Rev Esp Enferm Dig 2004; 96 (5): 322-30.

28. Pérez-Holanda S, Rodrigo L, Viñas-Salas J, Piñol-Felis C. Efecto de la ingesta de etanol en un modelo experimental de cáncer de colon. Rev Esp Enferm Dig 2005; 97 (2): 87-96.

29. Glauert HP, Bennink MR. Influence of diet or intrarectal bile acid injections on colon epithelial cell proliferation in rats previously injected with 1,2-dimethylhydrazine. J Nutr 1983; 113: 475-82.

30. Ma Q, Hoper M, Anderson N, Rowlands BJ. Effect of supplemental L-arginine in a chemical-induced model of colorectal cancer. World $\mathbf{J}$ Surg 1996; 20: 1087-91.

31. Grau de Castro JJ, Piqué Badía JM. Cáncer colorrectal. En: Monografías clínicas en oncología. Barcelona: Ed. Doyma SA 1990; 8 (6): 63-75.

32. Lev R. Adenomatous polyps of the colon: Pathological and clinical features. New York: Springer-Verlach Inc; 1990; 1-2. p. 1-18.

33. Morvay K, Szentléleki K, Török G, Pintér A, Börzsönyi M, Nawroth R. Effect of change of faecal bile acid excretion achieved by operative procedures on 1,2-dimethylhydrazine-induced colon cancer in rats. Dis Colon Rectum 1989; 32 (10): 860-3.

34. Tempero MA, Zetterman RK. Effects of sodium cholate on experimental carcinogenesis and cell proliferation in an excluded colonic segment. J Surg Oncol 1987; 36 (4): 253-8.

35. Bristol JB, Davies PW, Williamson RCN. Subtotal jejunoileal bypass enhances experimental colorectal carcinogenesis unless weight reduction is profound. En: Malt RA, Williamson RCN. Colonic carcinogenesis. MTP Press Limited, Harvard Medical School, Boston 1982; 26 : 275-81.

36. Kanazawa K, Mitsuoka T, Arai K, Yamamoto T, Hino Y. Amounts of intestinal microflorae in relation to colon carcinogenesis: an experi- mental study. Gastroenterol Jpn 1980; 15 (2): 177-83.

37. Winkler R, Pfeiffer M, Ayisi K, Dörner A. Spontaneous colostomy cancer in rat: a handly model of colonic carcinogenesis. En: Malt RA, Williamson RCN. Colonic carcinogenesis. MTP Press Limited. Boston: Harvard Medical School; 1982; p. 245-52.

38. Wakabayashi K, Nagao M, Esumi H, Sugimura T. Food-derived mutagens and carcinogens. Cancer Res. 1992; 52: 2092s-8s.

39. Obrador A, Benito E. Epidemiología. En: Grau JJ, Piqué JM. Monografías clínicas en Oncología: Cáncer colorrectal. Barcelona: Ed. Doyma; 1990. p. 1-11.

40. Cerdán FJ, Balsa T, Díez M, Martínez S, Torres-Melero J, Balibrea JL. Cáncer colorrectal: ¿Ha mejorado su diagnóstico en la última década? Rev Esp Enferm Dig 1996; 88 (1): 26-8.

41. López-Abente G, Pollán M, Aragonés N, Pérez Gómez B, Hernández Barrera V, Lope V, et al. State of cancer in Spain: incidence. An Sist Sanit Navar 2004; 27 (2): 165-73.

42. Bouché O, Faivre J. Cancers du côlon: Épidémiologie, facteurs de risque et dépistage. La lettre du cancérologue 1996 (Supl. 12): 20s-6s.

43. Martínez ME, Grodstein F, Giovannucci E, Colditz GA, Speizer FE, Hennekens C, et al. A prospective study of reproductive factors, oral contraceptive use, and risk of colorectal cancer. Cancer Epidemiol Biomarkers Prev 1997; 6 (1): 1-5.

44. Peipins LA, Newman B, Sandler RS. Reproductive history, use of exogenous hormones, and risk of colorectal adenomas. Cancer Epidemiol Biomarkers Prev 1997; 6 (9): 671-5.

45. Woodson K, Lanza E, Tangrea JA, Albert PS, Slattery M, Pinsky J, et al. Hormone replacement therapy and colorectal adenoma recurrent among women in the Polyp Prevention Trial. J Natl Cancer Inst 2001; 23: $1799-805$.

46. Chung H, Wu D, Gay R, Han SN, Goldin B, Bronson R, et al. Effect of age on susceptibility to azoxymethane-induced colonic aberrant crypt foci formation in C57BL/6JNIA mice. J Gerontol A Biol Sci Med Sci 2003; 58: B400-B405.

47. Choi SW, Friso S, Dolnikowski GG, Bagley PJ, Edmondson AN, Smith DE, et al. Biochemical and molecular aberrations in the rat colon due to folate depletion are age-specific. J Nutr 2003; 133: 120612.

48. Xiao ZQ, Moragoda L, Jaszewski R, Hatfield JA, Fligiel SE, Majumdar AP. Aging is associated with increased proliferation and decreased apoptosis in the colonic mucosa. Mech Ageing Dev 2001; 122 (15): 1849-64.

49. Morson B. The polyp-cancer sequence in the large bowel. Proc R Soc Med 1974; 67: 451-7.

50. Sutherland LA, Bird RP. The effect of chenodeoxycholic acid on the development of aberrant crypt foci in the rat colon. Cancer Lett 1994; 76 (2-3): 101-7.

51. Klurfeld DM. Dietary fiber-mediated mechanisms in carcinogenesis. Cancer Res 1992; 52 (Supl. 7): 2055s-9s.

52. O'Brien MJ, O'Keane JC, Zauber A, Gottlieb LS, Winawer SJ. Precursors of colorectal carcinoma: Biopsy and biologic markers. Cancer 1992; 70: 1317-27.

53. Goldin B, Gorbach SL. Alterations in faecal microflora enzymes related to diet, age, Lactobacillus supplements, and dimethylhydrazine. Cancer 1977; 40: 2421-6.

54. McGarrity TJ, Peiffer LP, Colony PC. Cellular proliferation in proximal and distal rat colon during 1,2-dimethylhydrazine-induced carcinogenesis. Gastroenterology 1988; 95: 343-8.

55. Park HS, Goodlad RA, Wright NA. The incidence of aberrant crypt foci and colonic carcinoma in dimethylhydrazine-treated rats varies in a site-specific manner and depends on tumor histology. Cancer Res 1997; 57 (20): 4507-10. 